\title{
PERILAKU MEMILIH PEMILIH PEMULA PADA PILKADA KABUPATEN SIDOARJO TAHUN 2015 DI KECAMATAN TAMAN
}

\author{
Suyono \\ Universitas PGRI Adi Buana Surabaya \\ Yonoabu05@gmail.com
}

\begin{abstract}
Abstrak
Pemilih pemula merupakan anak remaja yang berusia 17 tahun sampai 21 tahun dan sudah terdaftar di KPU Sidoarjo atau para pemilih yang sudah berusia di atas 21 tahun selama pemilihan dia tidak memlilih. Banyak para pemilih pemula gantrung dengan gadget, kontak tidak hanya bergaul dengan satu rumah tetapi sudah menjalin silaturrahmi, waktunya para pemilh pemula banyak digunakan dalam hal hal yang kurang efien, banyak yang belum paham apa artin memilih dalam demokrasi pilkada. Para pemilih Pemula kepemilikan $\mathrm{HP}$ dan sepeda motor untuk jalan-jalan dan berkumpul dan bisa mengakses ke media sosial baik regional maupun internasional, maka banyak para pemilih pemula kurang memperhatikan arti pentingnya politik khususnya demokrasi pilkada sidoarjo 2015. Disinilah perlunya seorang aktor untuk mengadakan pendidikan demokrasi pilkada sidoarjo tahun 2015. Para pemilih pemula sangat penting untuk diperkenalkan Demokrasi melaui diskusi. Teknik strategi pendidikan demokrasi melalui pada para pemilih pemula melalui obrolan yang dikenalkan oleh peneliti. Cara seperti ini adalah cara yang paling efektif para pemilih pemula merasa dekat dengan aktor seperti dekat dengan orang tua. Penelitian ini menggunakan metode Deskripsi kualitatif, Informan dalam penelitian ini Pemilih Pemula di Kecamatan Taman Hasil Penelitian dapat menganalisis Perilaku pemilih pemula dalam Pilkada Kabupaten Sidoarjo Tahun 2015 di Kecamatan Taman dan mendiskripsikan kendala-kendala pemilih Pemula dalam menentukan pilihannya pada Pemilhan Bupati Sidoarjo Tahun 2015 di Kecamatan Taman. Dengan pendekatan seperti ini para pemilih pemula tidak canggung, dan pemilih pemula termotivasi untuk memahami berbagai isu politik dan tidak canggung lagi dalam berpartisipasi dalam demokrasi pilkada 2015.
\end{abstract}

Kata kunci: Pemilih Pemula, Perilaku Pemilih dan Pilkada.

\section{PENDAHULUAN}

Demokrasi adalah adalah bentuk Pemerintahan dari Rakyat oleh rakyat dan untuk rakyat. Rakyat Indonesia telah memilih Demokrasi sebagai dasar penyelenggaraan Negara. Pemilihan umum sebagai sarana pelaksanaan demokrasi wajib dilaksanakan secara demokratis. UU No. 10 tahun 2008 dalam Bab. IV pasal 19 dan 2 serta pasal 20 menyebutkan bahwa yang dimaksud pemilih pemula adalah warga Indonesia yang pada hari pemilihan atau pemungutan suara adalah warga negara Indonesia yang genap berusia 17 tahun dan atau lebih atau sudah pernah kawain yang mempunyai hak pilih, dan sebelumnya belum termasuk pemilih karena ketentuan 
Undang- Undang Pemilu. Pemilih Pemula juga merupakan bagian dari dari Pemilih Kabupaten Sidoarjo yang mempunyai peran besar kemajuan rakyat Sidoarjo dan tidak boleh dianggap remeh dan disepelekan.

Berdasarkan data yang diperoleh dari KPUD Kabupaten Sidoarjo, jumlah pemilih Kabupaten sidoarjo tahun 2015 yang memiliki hak pilih sebanyak 1.367.945 dengan perincian hak pilih Perempuan 693.996, hak pilih lakilaki 673.949. dari jumlah tersebut pemilih pemula yang mempunyai hak pilih 13.035 dengan perincian untuk pilih laki-laki 6.798 dan hak pilih perempuan 6.237

Berbagai informasi terkini baik berupa isu maupun berita selalu dikaitkan dengan demokrasi. Demokrasi menurut David Beethm dan Kevin Boyle (2000) adalah bagian dari khasanah dalam membuat keputusan secara kolektif. Demokrasi berusaha untuk mewujudkan keinginan bahwa keputusan yang mempengaruhi perkumpulan secara keseluruhan harus diambil oleh anggota dan masing-masing anggota mempunyai hak yang sama dalam proses pengambilan keputusan. Dengan demokrasi keinginan rakyat atau aspirasi rakyat dalam hal ini semua masyarakat mempunyai hak yang sama. Dengan demokrasi sejauh mana kendali masyarakat dan kesetaraan politisi dalam mengambil keputusan secara kelompok. Menurut Juan dan Alfred (2001:26) Demokrasi adalah persaingan terbuka untuk mendapatkan hak menguasai pemerintah. Diharapkan dengan demokrasi dilaksanakan melalui pemilu yang bebas dan kompetitif sehingga menghasilkan pemimpinpemimpin atau orang-orang yang memerintah.

Menurut Gabriel A. Almond (1984) demokrasi adalah sistem pemerintahan banyak orang biasa disebut rule by the people, yang artinya pemerintahan dari rakyat, oleh rakyat dan untuk rakyat. Maksudnya rakyat yang mempunyai mayoritas suara sangat menentukan dalam proses perumusan kebijakan pemerintah melalui saluran-saluran yang tersedia (infra struktur politik) yaitu melalui partai politik, kelompok kepentingan, kelompok penekan dan pendapat umum

Menurut Hert (1979) dalam buku political realism and political idealism menyatakan bahwa Demokrasi adalah semacam pemerintahan dimana tidak ada seorang anggota masyarakat atau kelompokpun yang mempunyai hak 
prerogratif politik (yang tidak boleh diganggu gugat oleh siapapun juga) atas orang lain. Dengan demokrasi kita sebagai warga Negara yang baik, harus memahami dan menerima hal yang baik semua keputusan yang telah diambil oleh pemerintah, satu atau kelompok orang, jadi warga Negara harus taat dan patuh semua yang diputuskan pemerintah masyarakat harus menerima semua dan tidak boleh mengganggu gugatnya.

Menurut Ramlah Surbakti (2010:290) demokrasi adalah memungkinkan perbedaan pendapat, persaingan dan pertentangan diantara individu, diantara berbagai kelompok, diantara individu dan kelompok, individu dengan pemerintah, bahkan antara lembaga pemerintah. Dalam demokrasi interaksi antara individu dengan individu, antara individu dengan kelompok, kelompok dengan kelompok dan bahkan antar lembaga pemerintah, dalam interaksi ada perbedaan pendapat antara yang satu dengan yang lain dan tidak sampai merusak demokrasi sendiri.

Perkembangan jaman era reformasi ini dicirikan oleh dinamika anak-anak muda yang tinggi. Dinamika tersebut berbentuk fisik maupun non fisik. Secara fisik, pergaulan anak-anak muda itu jauh melampui batas-batas wilayah otonomi mereka. Jika sebelumnya Pemilih Pemula di masa dahulu (terutama pada dekade tujuh puluhan), masih bergaul di sekitar kampung atau sebelah menyebelah kampung di kabupaten Sidoarjo, kini dengan begitu banyaknya sepeda motor yang menjadi kepemilikan masyarakat, mereka mampu bergaul jauh melintasi kampung, desa, kecamatan bahkan kabupaten. Alat transportasi ini memungkinkan bagi mereka melakukan interaksi sosial lintas wilayah. Perkembangan teknologi modern yang mengandalkan ponsel, yang di dalammnya ada program WA, facebook, internet atau apapun yang sifatnya nirkabel, membuat pergaulan mereka melintasi provinsi, negara bahkan benua. Pergaulan di internet membuat mereka mampu melakukan kontak sosial dengan rekan-rekan mereka sesama pemilih pemula yang ada di negara lain.

Para pemilih pemula pada membawa Sepeda motor dan Gadget mereka kumpul-kumpul baik siang, sore maupun malam hari, tempat berkumpul dicafe café, dan warung kopi, ada di tempat tertentu yang penting cocok untuk berkumpul 4 orang atau 5 orang, pesan kopi, atau teh, susu atau ditambah snack Tanya 
password pada pelayan Café, dari yang hadir memainkan HP untuk brossing internet, atau buka WA atau main game mulai siang hari sampai malam Pendidikan pemilih pemula beragam dari Sekolah Menangah Atas (SMA), SMK sampai dengan mahasiswa tingkat awal atau semester empat.

Para pemilh pemula dalam pemilu adalah warga Negara yang berumur sudah mencapai 17 tahun atau sudah pernah menikah pada saat coblosan, para pemilih pemula mereka rata-rata berumur 17 tahun sampai 21 tahun atau para pemilih yang berumur diatas 21 tahun yang selama ini belum pernah menggunakan hak pilihnya. Para pemilih pemula yang sedang getolgetolnya untuk berkumpul bersama memberi pengalaman dengan pihak lain.

Para pemilih pemula kebanyakan kurang memahami arti dan tujuan demokrasi pilkada sidoarjo tahun 2015, yang dia ketahui bahwa pilkada biasanya seorang calon bupati bagi-bagi uang atau memberi sumbangan pada warga desa dan warga desa termasuk para pemilih pemula wajib memilih calon tersebut, walapun calon tersebut belum diketahui trek recordnya serta visi, misi dan tujuan kalau jadi bupati sidoarjo kalau nantinya terpilih, maka melihat fenomena tersebut peneliti berkewajiban untuk meneliti perihal terebut.

Dengan berkumpulnya para pemilih pemula, dengan mudah untuk memberi nasihat-nasihat kepada mereka cara melaksanakan pencoblosan pada waktu pencoblosan pilkada

Sidoarjo tahun 2015, dengan menekankan membangun kepercayaan diri dalam memilih tanpa harus dipengaruhi oleh pihak lain. Sebagai pemilih pemula pemasukan seperti ini sangat dibutuhkan oleh para pemilih pemula untuk memutus kebiasaan dari memilih sebelumnya yang banyak dipengaruhi dengan cara-cara tertentu demi kepentingan seorang calon. Diantara cara itu adalah memberikan uang pada calon pemilih sebelum pelaksaan pilkada atau membri sumbangan pada kampung sebelum pelaksanaan pilkada. Dalam penilaian para pemilih pemula kalau sudah diberi uang kita harus memilih pada seorang calon pilkada tersebut. Pendapat-pendapat seperti ini harus diperbaiki pemahamannya pada para pemilih pemula tersebut. Maka perlu dijelaskan pada para pemilih pemula suatu kepercayaan diri untuk memilih, tidak ada keharusan untuk memilih seseorang calon Bupati berdasar pemberian uang dan 
sumbangan pada kampung halaman. Perilaku pemilih pemula masih berhubungan erat dengan faktor sosiologis, dan psikologis dalam menjatuhkan pilihannya jika ditinjau dari studi Voting behaviors. Yang membedakan antara pemilih Pemula dengan pemilih lainnya adalah soal pengalaman menghadapi politik dalam pilkada, dan Pemilu. Pendekatan sosiologis dan psikologis menempatkan individu sebagai obyek yang tidak bertindak bebas karena ditentukan oleh struktur sosial dan aspek psikis, sementara pilihan rasional menempatkan individu sebagai aspek yang bebas atau Voluntary dalam menentukan pilihannya.

\section{KAJIAN PUSTAKA}

Perilaku dapat dipahami sebagai pikiran atau tindakan manusia yang berkitan dengan proses pemerintahan. Perilaku politik adalah tanggapan- tanggapan internal (pikiran, persepsi, sikap, dan keyakinan) dan juga tindakan yang nampak (pemungutan suara, gerak protes, lobi dan kampanye) jadi perilaku juga diartikan sebagai tindakan-tindakan dari perilaku individu tertentu.

Perilaku pemilih adalah tingkah laku seseorang dalam menentukan pilihannya yang dirasa paling disukai atau paling cocok. Kecocokan masyrakat dalam menentukan dan melakukan perubahan sikap dan perilaku dalam berbagai kehidupan sosial ekonomi, sosial politik maupun sosial budaya, terbatas adanya sistem ide atau gagasan dari tokoh masyarakat untuk merubah sistem sosial dan sistem budaya yang sudah mapan dalam kehidupan masyarakat disesuaikan dengan kondisi dan dinamika masyarakat.

Pada kelompok masyarakat yang heterogen cenderung lebih bersifat rasional, pragmatis tidak mudah untuk dipengaruhi, berurentasi pada materi, dengan mengeluarkan ongkos yang sekecilkecilnya untuk mendapatkan hasil yang sebesar-besarnya. Tingkat kesadaran dan perilaku politiknya ditentukan oleh sikap dan pandangan untuk memilih dan tidak memilih pada proses politik yang lebih besar. Sehingga tingkat kesadaran dan perilaku memilih ditentukan oleh sikap dan pandangan individu yang bersangkutan, tidak segampang dipengaruhi oleh pemuka atau kelompok tertentu.

Pilkada merupakan kesempatan yang paling diutamakan untuk memilih pasangan Bupati dan Wakil bupati secara langsung, dan berkualitas. Kesuksesan Pilkada tidak 
diukur dari sukesnya acara melainkan manfaat dan hasil yang diperoleh. Bupati dan Wakil Bupati dipilih secara langsung oleh Warga Masyarakat Sidoarjo termasuk pemilih Pemula yang dipilih secara langsung, umum bebas, dan rahasia, jujur dan berkeadilan.

Pendidikan Demokrasi adalah upaya sistematis yang dilakukan oleh warga Negara dan masyarakat untuk memfasilitasi individu warga Negara agar memahami, menghayati dan mengamalkan dan mengembangkan konsep, prinsip dan nilai demokrasi sesuai dengan status dan perannya di masyarakat (Udin S. Winataputra, 2012). Dengan tujuan mempersiapkan masyarakat untuk bertindak dan berprilaku demokratis dalam interaksinya dengan masyarakat baik seara individu maupun kelompok dalam kehidupan sehari-hari. Melalui aktifitas yang ditanamkan pada generasi muda akan pengetahuan, kesadaran, dan nilai-nilai demokrasi.

Menurut Zamroni (2001) pengetahuan dan kesadaran akan nilai-nilai demokrasi itu meliputi tigahal. Pertama kesadaran bahwa demokrasi adalah pola kehidupan yang paling menjamin hak-hak warga masyarakat itu sendiri, demokrasi adalah pilihan terbaik diantara yang buruk tentang pola hidup bernegara. Kedua, demokrasi adal sebuah learning proses yang lama dan tidak sekedar meniru dari masyarakat lain. Ketiga, kelangsungan demokrasi tergantung pada keberhasilan mentransformasikan nilai-nilai demokrasi pada masyarakat. Menurut Zamroni (2001) Tanpa manusia yang memegang teguh nilai-nilai demokrasi, masyarakat yang demokrasi hanya akan merupakan impian belaka. Sistem demokrasi yang langgeng apabila didukung masyarakat yang demokratis dan setiap pemerintahan yang demokratis akan melaksanakan sosialisasi nilainilai demokrasi pada generasi muda khususnya pemilih pemula.

Pendidiikan demokrasi tidak identik dengan sosialisasi politik. sosialisasi politik mencakup yang sangat luas sedangkan pendidikan demokrasi sangat sempit, sedangkan makna pendidikan suatu proses yang sadar terencana, terprogram, terencana, terorganisasi secara baik melalui pendidikan formal. Sedangan penedidikan non formal demokrasi sebalik kurang terencana dan terorganisasi tetapi tetap diinformasikan nilai-nilai demokrasi pada generasi muda khususnya pemilih pemula secara terus menerus dan kesinambungan, waktu dan lokasi mengikuti pada kegiatan Generasi muda, iformasi yang 
disampaikan tentang pentingan tentang sikap, dan berprilaku demokrasi dalam kehidupan seharihari.

Keikutsertaan warga Negara dalam pilkada merupakan bagian tahapan serangkaian dalam pembuatan keputusan, apakah memilih atau tidak memilih dalam pilkada. Apakah memilih kandindat sesuai dengan pilihannya. Dalam menentukan pilihannya terhadap kandidat yang akan dipilih dalam pilkada dibedakan menjadi lima sesuai dengan pendekatan yang digunakan yakni struktural, sosiologis, psikologis sosial dan pilihan rasional.

Pendekatan struktural melihat kegiatan pemilih sebagai produk dari konteks struktur yang lebih luas, seperti struktur sosial, system partai, system pemilihan umum, permasalahan dan program yang ditonjolkan oleh kandidat dari Bupati tersebut. Struktur sosial merupan kemajemukan politik dapat berupa kelas sosial atau ada perbedaan perbedaan antara majikan dan buruh, agama, kota, desa, bahasa dan nasionalisme dan programprogram yang ditonjolkan.

Pendekatan sosiologis, cenderung kegiatan memilih dalam kaitannya dengan konstek sosial. Pilihan pemilih pemula dipengaruhi oleh beberpa faktor, demografi, sosiologis, sosial ekonomi, jenis kelamin, tempat tinggal (kota desa) pekerjaan pendidikan, kelas, pendapatan dan agama.

Pendekatan ekologis, sangat relevan apabila dalam suatu daerah pilihan terdapat perbedaan karakteristik pemilih berdasarkan unit territorial seperti, desa, kelurahan, kecamatan dan kabupaten. Pendekatan ekologis ini penting sekali digunakan karena karakteristik untuk tingkat Selanjutnya karakteristik pendekatan secara rasional memilih kegiatan memlih sebagai produk kalkulasi untung dan rugi. Pendekatan secara rasional tidak hanya untung dan rugi, yang tidak dipertimbangkan untung dan rugi suaranya dapat mempengaruhi terutama untuk membuat keputusan untuk menimpang dan untuk memutuskan. Di Negara berkembang hak untuk memilih belum ada kesadaran untuk menggunakan hak pilihdan masih banyak dipengaruhi oleh rekan sepermainan, saudaranya, orang tua dan bapak /Ibu Guru, bahkan ada ancaman atau solusi. Bukan malah sebaliknya untuk kegiatan kepada mahasiswa ditentukan oleh tekanan kelompok, intimidasi dan paksaan dari kelompok dan atau pemimpin teretentu. 
Perilaku Memilih tidak lepas daripada paritipasi politik, partisipasi politik merupakan aspek penting dalam demokrasi. Asumsi yang mendasari demokrasi adalah orang yang paling baik untuk dirinya sendiri adalah orang itu sendiri. Keputusan yang dibuat dan dilaksnakan oleh pemerintah menyangkut dan mempengaruhi kehidupan masyarakat, masyarakat berhak ikut serta menentukan isi keputusan politik.

Menurut Ramlan Surbakti (2010:180) partisipasi politik adalah keikutsertaan warga Negara biasa dalam menentukan segala keputusan yang men yangkut atau mempengaruhi hidupnya. Pemerintah yang memiliki kewenangan membuat dan melaksanakan keputusan politik, sedangkan masyarakat tidak memilki kewenangan. Akan tetapi masyarkat ikut berhak untuk mempengaruhi proses pembuatan dan pelaksanaan keputusan. Kegiatan warga Negara biasa, bisa dibagi dua yaitu mempengaruhi isi kebijakan umum dan ikut menentukan pembuat dan pelaksanaan keputusan politik. Hal konseptualisme tentang partisipasi politik.

Konseptualisasi merupakan upaya untuk menyusun ramburambu sebagai criteria untuk menentukan apakah suatu fakta termasuk dan tidak termasuk kedalam konsep itu. Rambu rambu partisipasi politik berupa kegiatan atau perilaku di luar individu sebagai warga Negara dapat diamati, dan kegiatan diarahkan pada pemerintah selaku pembuat dan pelaksana keputusan politik. dan kegiatan yang berhasil maupun yang gagal mempengaruhi pemerintah termasuk konsep partisipasi politik, dalam mempengaruhi pemerintah individu bisa bertindak langsung atau melalui pihak kedua. Individu dalam mempengaruhi pemerintah, ada yang dilakukan atas kesadaran sendiri ( kegiatan otonom atau self motion) dan individu dalam mempengaruhi pemerintah atas desakan, manipulasi, dan paksaan dari pihak lain, hanya strategi pemasaran politik yang sukses.

\section{METODE PENELITIAN}

Lokasi penelitian di Kecamatan Taman Kabupaten Sidoarjo pada bulan 2 April 2017 sampai dengan September 2018. Metode penelitian deskriptif kaulitatif, dalam penelitian yag berubungan dengan masyarakat, penelitian menguji secara keseluruhan. Adapun informan yang akan diwawancarai secara mendalam adalah Ketua PPK Kecamatan Taman, Ketua KPU Kecamatan Taman, unsur-unsur Pemerintah 
Kecamatan Taman dan unsur-unsur lain yang terkait dengan Pilkada Kabupaten Sidoarjo Tahun 2015, Sedangkan responden dari penelitian ini adalah beberapa pemilih pemula yang menggunakan hak pilihnya pada pemilihan Pilkada Kabupaten Sidoarjo Tahun 2015, yang berusia antara 17 tahun - 21 tahun yang ada di Kecamatan Taman Kabupaten Sidoarjo.

Sumber data Primer dan sumber data skender. Data primer diperoleh peneliti melalui langsung wawancara mendalam ke lokasi dengan informan yang dituju. Sedangkan data sekunder peneliti diperoleh dari kepustakaan, dokumen, buku, hasil penelitian yang terkait dengan penelitian. Reduksi data penelitian ini mengikuti langkah-langkah Milles dan Huberman yaitu (1) reduksi data (2) penyajian data dan (3) pengambilan kesimpulan. Keabsahan data mengikuti data yang dilakukan Moleong Patton dalam (Moleong, 1991: 330) bahwa triangulasi dengan sumber dan triangulasi dengan metode.

\section{HASIL DAN PEMBAHASAN}

\section{Hasil Penelitian}

Pemilih Pemula merupakan objek dari penelitian ini, mereka yang memiliki usia 17 tahun sampai
21 tahun. Pemilih Pemula di Kecamatan Taman Kabupaten Sidoarjo pada tahun 2015 berjumlah 13.035 dari 1.367 .945 orang masyarakat pemilih yang telah memberikan suaranya.

\section{Pembahasan}

Pada pembahasan akan diuraikan tiga aspek pada penelitian yaitu

a. Perilaku Politik Pemilih Pemula pada pemilihan pasangan Bupati dan Wakil Bupati Kabupaten Sidoarjo Tahun 2015 di Kecamatan Taman.

Perilaku Pemilih Pemula di Kecamatan Taman Kabupaten Sidoarjo dalam menentukan atau menjatuhkan pilihannya pada Pilkada Kabupaten Sidoarjo Kecamatan Taman tahun 2015. Perilaku yang ikut-ikutan pada pemilih pemula dikarekan mereka belum mampu melihat karakteristik dari Pemimpin tepat yang akan dipilihnya. Selain itu keputusan politik belum mantab pada calon pemimpin yang akan dilihnya, gampang mudah untuk menerima pengaruh dari lingkungan kelompok sosial yang telah terbentuk di tempat tinggal mereka, khususnya dalam lingkungan keluarga dan kedua orangtua. Perilaku pemilih pemula dapat dilihat dari tiga pendekatan yaitu

(a) Pada umumnya disebabkan 
faktor lingkungan sosial politik langsung yang mempengaruhi dan membentuk kepribadian pemilih pemula. Menurut penulis pemilih pemula tersebut dalam menjatuhkan pilihannya dipengaruhi latar belakang lingkungan tempat tinggal, yakni lingkungan keluarga dimana para pemilih tinggal. Dari lingkungan sosial politik langsung sebagai pemilih pemula mengalami sosialisasi dan internalisasi nilai, dan norma masyarakat, termasuk nilai dan norma kehidupan bernegara dan pengalamanpengalaman hidup pada umumnya. Ada kecenderungan yang menempatan kegiatan memilih pada kaitannya dengan kontek sosial. Realitasnya pilihan pemilih pemula dalam Pilkada dipengaruhi latar belakang demografi dan sosial ekonomi, jenis kelamin, tempat tinggal (pinggiran kota- desa), Pekerjaan, pendidikan, penghasilan dan Agama.

(b) Struktur kepribadian yang tercermin dalam sikap individu. Menurut penulis untuk memahami stuktur kepribadian perlu dicatat terdapat 3 basis fungsional sikap yaitu kepentingan, penyesuaian diri, eksternalisasi dan pertahanan diri. Basis yang pertama merupakan sikap yang menjadi fungsi kepentingan. Artinya penilaian pemilih pemula terhadap pasangan calon bupati ditetukan minat dan kebutuhan atas pasangan calon bupati tersebut. Basis kedua merupakan sikap yang menjadi fungsi penyesuaian diri . artinya penilaian terhadap suatu pasangan calon bupati tersebut. Basis yang ketiga merupakan sikap yang menjadi fungsi eksternalisasi diri dan pertahanan diri. Artinya artinya penilaian pemilih pemula terhadap pasangan calon bupati dipengaruhi oleh keinginan untuk mengatasi konflik batin atau tekanan psikis yang mungkin terwujud mekanisme pertahanan diri dan eksternalisasi diri, yaitu rasionalisasi

(c) faktor lingkungan sosial politik langsung berupa situasi, yaitu keadaan yang mempengaruhi pemilih pemula secara langsung ketika hendak melakukan pemungutan suara pada Pilkada sidoarjo, seperti sosialisasi Pilkada sidoarjo. Faktor lingkungan sosial langsung berupa sosialisasi pilkada Sidoarjo akan mempengaruhi secara langsung salah satu faktor yang mencakup yang mencakup struktur kepribadian atau sikapnya terhadap Pilkada tersebut. 
b. Kendala-kendala yang dialami pemilih pemula pada pemilihan Kepala derah Kabupaten Sidoarjo Kecamatan Taman tahun 2015

Adapun kendala-kendala yang di alami pemilih pemula yaitu (1) Kebimbangan politik yaitu sifat mengikuti arus para pemilih pemula dalam menyalurkan aspirasinya terhadap pemilihan kepala daerah; (2) Kendala usia karena untuk mengikuti proses Pilkada diawali Penjaringan bakal calon, menetapkan calon tetap, proses sosialisasi, proses kampanye dan keinginan untuk mengikuti kegiatan proses Pilkada, mengikuti diskusi, sosialisasi, menjadi pendukung pasangan satu calon Kepala daerah, kegiatan semacam ini pemilih pemula kurang diberi tempat untuk sekedar berpartisipasi tetapi yang banyak diberi kesempatan adalah orang dewasa atau orang tua. (3) kendala latar belakang calon yaitu belum diketahui secara mendalam perihal pribadi dan track record-nya dari Pasangan calon Kepala Daerah dan Wakil Kepala Daerah. Kurang gencarnya memperkenalkan diri dan promosi dari pasangan calon Kepala Daerah, untuk terjun dari desa ke des, untuk mendapatkan simpati khususnya dari kaum pemilih pemula. (4) sosilasi dari
KPUD atau dari relawan yang ditunjuk KPUD belum menyeluruh belum semua desa sekabupaten Sidoarjo khususnya bagi para pemilih pemula, sehingga visi, misi dan tujuan bagi para kandidat kurang diperoleh.

\section{SIMPULAN}

Berdasarkan hasil penelitian dapat disimpulkan bahwa Perilaku pemilih Pemula pada pemilihan Kepala Daerah Kabupaten Sidoarjodi kecamatan Taman tahun 2015, menunjukkan perilaku pemilih Pemula pada pelaksanaan Kepala Daerah kabupaten Sidoarjo di kecamatan Taman tahun 2015, menunjukkan perilaku Politik Pemilih Pemula dalam melaksanakan Pemilihan Kepala Daerah Kabupaten Sidoarjo di Kecamatan Taman tahun 2015 ditunjukkan tiga pendekatan yaitu:

a. Pada umumnya dikarenakan faktor lingkungan sosial politik langsung yang mempengaruhi dan membentuk kepribadian pemilih pemula., Menurut penulis pemilih pemula tersebut dalam menjatuhkan pilihannya dipengaruhi latar belakang lingkungan tempat tinggal, yakni lingkungan keluarga dimana para pemilih tinggal. dan faktor lingkungan sosial politik langsung menjadi 
alasan para pemilih pemula menjatuhkan pilihannya terhadap pasangan calon Kepala daerah .

b. Struktur kepribadian yang tercermin dalam sikap individu. Menurut penulis untuk memahami stuktur kepribadian perlu dicatat terdapat 3 basis fungsional sikap yaitu kepentingan, penyesuaian diri, eksternalisasi dan pertahanan diri. Basis yang pertama merupakan sikap yang menjadi fungsi kepentingan. Artinya penilaian pemilih pemula terhadap pasangan calon bupati ditetukan minat dan kebutuhan atas pasangan calon bupati tersebut.

c. faktor lingkungan sosial politik langsung berupa situasi, yaitu keadaan yang mempengaruhi pemilih pemula secara langsung ketika hendak melakukan pemungutan suara pada Pilkada sidoarjo, seperti sosialisasi Pilkada sidoarjo, sehingga terbentuk perilaku yang rasional dan efisien.

\section{DAFTAR PUSTAKA}

Almond, Gbriuel A. 1984. Budaya Politik: tingksh laku politik $d n$ demokrasi di Indonesia. Jakarta: Bina Aksara.

Budiardjo, Miriam. 2014. Dasar-dasar ilmu politik. Jakarta: Gramedia.

Duverger, Maurice. 2013. Sosiologi Politik. Jakarta: Rajawali Pers.
David Beetham \& Kevin Boyle. 2000.

Demokrasi : 80 tanya jawab. Yogyakarta: Kanisius.

Hertz John, H. 1959. Political realism and political idealism, University of Chicago. Press USA.

Juan J. Linz dan Alfred Stepan. 2001. Defining and cratifing Democratic transition constitions and consolidation dalam Juan J. linz et.al. menjahui demokrasi kaum penjahat, belajar dari kekeliruan Negara-negara lain. Bandung: Mizan.

Marijan, Kacung. 2012.Sitem politik Indonesia : konsolidasi pasca orde baru.Jakarta: Kencana.

Mufti, Muslim, 2013.Teori-teori demokrasi. Bandung: Pustaka Setia.

Moleong, J. Lexi 2005. Metodologi Penelitian Kualitatif. Remaja Roskakarya, Bandung.

Ramlan, Surbakti. 2010. Memahami ilmu politik. Jakarta: Grasindo. Riyanto, E. Armada. 2014. Berfilsafat Politik. Yogyakarta: Kanisius. Sukarno. 1979. Sistem Politik. Bandung: Alumni

Udin S. Winataputra. 2012. Pendidikan Kewarganegraan dalam Perspektif Pendidikan untuk Mencerdaskan Bangsa. Bandung: Widya Aksara Press Undang-Undang No 22 Tahun 200'7 
Tentang Penyelenggaraan

Pemilu.

Winarno. 2014. Paradikma Baru

Pendidikan Kewarganegaraan:

Panduan kuliah di Perguruan

Tinggi. Jakarta: Bumi Aksara.

Zamroni. 2001. Pendidikan untuk

Demokrasi. Yogyakarta: Bigraf

Publising. 